\title{
PENILAIAN RANAH AFEKTIF DALAM BENTUK PENILAIAN KETERAMPILAN MENULIS DENGAN MODEL PEMBELAJARAN THINK TALK WRITE (TTW) MENGGUNAKAN MEDIA AUDIOVISUAL PADA SISWA SEKOLAH DASAR
}

\author{
Veronika Unun Pratiwi ${ }^{1}$, Nofrahadi ${ }^{2}$, Apri Pendri ${ }^{3}$, Dina Komalasari ${ }^{4}$, Sumarwati ${ }^{5}$ \\ Universitas Veteran Bangun Nusantara, Indonesia ${ }^{1}$, Universitas Sebelas Maret, Indonesia ${ }^{2,3,5}$, \\ Universitas Muhammadiyah Buton, Indonesia ${ }^{4}$ \\ veronikaununpratiwi@student.uns.ac.id ${ }^{1}$, nofrahadi11@ student.uns.ac.id $^{2}$,

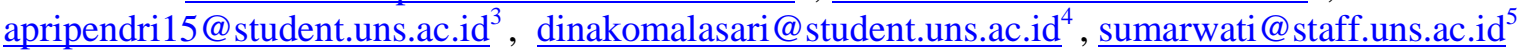

\begin{abstract}
Permendikbud No. 66/2013 concerning assessment standards explains that the assessment techniques and instruments used in the 2013 Curriculum include competency assessment of attitudes, knowledge, and skills. This means that learning and assessment must develop students' competencies related to the affective, cognitive, and psychomotor domains. Assessment of the affective domain is important because assessing the affective domain must be carried out in learning activities. The education unit needs to design and develop an appropriate affective domain assessment to achieve optimal learning objectives. In this study, the affective domain rating scale uses skills assessment using a Likert scale. Think Talk Write is a learning model that can improve activity and communication among students. Ngalimun argues that the Think Talk Write learning model is a type of learning model that starts with thinking through the reading material, communicated with presentations, discussions, and then reports on the presentation results.
\end{abstract}

Keywords: Affective, Think Talk Write, Audiovisual Media

\begin{abstract}
ABSTRAK
Permendikbud No. 66 / Tahun 2013 bagian Standar Penilaian menjelaskan bahwa teknik dan perangkat penilaian yang digunakan dalam kurikulum 2013 meliputi penilaian sikap, pengetahuan, serta keterampilan. Dalam kata lain, pembelajaran dan penilaian harus mengembangkan kompetensi siswa dalam kaitannya dengan aspek afektif, kognitif, dan psikomotorik. Penilaian ranah afektif adalah hal yang krusial, lantaran evaluasi ranah afektif wajib dilakukan pada aktivitas belajar dan pembelajaran. Unit pembelajaran perlu merancang dan berbagi evaluasi ranah afektif yang sempurna supaya tujuan pembelajaran dapat tercapai secara optimal. Penelitian ini menggunakan Skala likert untuk menilai ketrampilan ranah afektifnya. Kemudian Model pembelajaran Think Talk Write di terapkan sebagai model pembelajaran yang terbukti meningkatkan komunikasi dan aktivitas diantara siswa. Ngalimun berpendapat bahwa model pembelajarn tersebut ialah model yang diawali dengan berfikir melalui materi bahan bacaan kemudian di komunikasikan dengan presentasi, diskusi, dan pelaporan penyajian materi.
\end{abstract}

Kata Kunci: Afektif, Think Talk Write, Media Audiovisual

\section{PENDAHULUAN}

Permendikbud No.66 Tahun 2013 pada standar penilaian menjelaskan bahwa dalam
Kurikulum 2013 cakupan komptetnsinya ialah sikap, pengetahuan, serta ketrampilan. Dengan kata lain, ranah afektif (sikap), kognitif 
(pengetahuan), dan psikomotorik (ketrampilan) dapat ditingkatkan melalui pembelajaran dan evaluasi, sehingga kompetensi peserta didik menjadi berkembang.

Penilaian dalam ranah kognitif melibatkan keterampilan berpikir, meliputi kemampuan mengingat, memahami, menerapkan, menganalisis, mengintegrasikan, dan mengevaluasi. Penilaian ranah psikomotorik termasuk keterampilan motorik dan saraf otot, contohnya menulis dan berbicara. Kemudian dalam domain afketif berkaitan dengan preferensi dan sikap seperti kejujuran, disiplin, dan kepercayaan diri. Pada dasarnya kita tidak dapat memisahkan ketiga ranah ini karena itu berkaitan satu dan yang lain dengan jelas. Karena jika telusuri pada paradigma lama, proses belajar dan pembelajaran sangat diprioritaskan pada kemampuan kognitif siswa. Di sisi lain, untuk mencapai tujuan belajar yang baik, harus memiliki segala aspek (kognitif, afektif, serta psikomotorik) yang seimbang.

Seperti yang telah dijelaskan pada pembahasan sebelumnya, dari ketiga aspek tersebut, aspek ranah afektif menjadi penting untuk dilakukan mengingat penilaian ranah ini berperan dalam keberhasilan tujuan pembelajaran. Popham, (dalam Djemari Mardapi, 2004) tegas mengatakan bahwa domain afektif menentukan keberhasilan bagaimana murid bersikap. Oleh karena itu, pembelajaran harus memperhatikan aktivitas penilaian pada aspek afektif ini. Unit pendidikan perlu dirancang dan dikembangkan dengan penilaian yang tepat terhadap ranah ini agar dapat mencapai tujuan pembelajaran secara optimal dikarenakan perkembangan penilaian mampu memberikan dampak yang sangat positif bagi sekolah, khususnya sekolah dasar.

Penilaian ranah afektif dapat disusun dalam bentuk skala Likert atau skala semantic differential. Pada penelitian ini, skala penilaian ranah afektif menggunakan penilaian keterampilan skala Likert karena dalam penelitian ini mengukur capaian-capaian peserta didik dalam hal keterampilan menulis dalam bentuk checklist. Instrumen penilaian keterampilan tersebut dapat mengetahui keterampilan peserta didik terhadap materi integral.
Penyusunan asessmen afektif dapat menggunakan Skala semantic differental atau biasa disebut dengan Skala Likert. Penelitian ini menggunakan penilaian ketrampilan lantaran dalam penelitian ini mengukur pencapaian murid dalam bentuk cheklist. Alat penliaian keterampilan ini dapat mengidentifikasi keterampilan murid pada materi integral. Keterbatasan pada permasalahan di artikel ialah hanya pada penilaian afektif, pengembangan penilaian skala keterampilan dan penggunaan skala likert.

Artikel ini bertujuan memberikan wawasan mengenai pengembangan alat penilaian skala katerampilan yang dapat digunakan untuk mengukur kemampuan siswa pada ranah afektif.

\section{METODOLOGI PENELITIAN}

Artikel ini berfokus kepada penialian personal yang merupakan metode penilaiannya diimplementasikan dengan cara meminta peserta didik untuk menngemukakan kelebihan serta kekurangan mereka dalam cakupan pencapaian kompetensinya. Beberapa lembar angket disebarkan sebagai instrumen yang digunakan. Penyusunan lembaran angket dibuat berdasarkan kaidah kisi-kisi instrumen pada skala ketrampilan

Pratiwi (2015:14) menjelaskan bahwa dalam menerapkan penelitian kuantitatif, pemeran utamanya ialah peneliti itu sendiri. dengan instrumen utamanya ialah wawancara, pengamatan atau observasi dengan melakukan checklist pada angket, serta metode dokumentasi meliputi foto, rekaman, yang akan didukung dengan peralatan seperti proyektor, laptop, LCD, Slide dan alat tulis.

\section{HASIL DAN PEMABAHASAN Pengertian Keterampilan Menulis}

1. Pengertian Menulis

Istilah menulis dan mengarang adalah dua hal yang memiliki arti yang sama bagi sebagian para ahli. Menulis adalah keterampilan berbahasa yang pada dasarnya harus dimiliki oleh peserta didik. Setiap individu harus mempunyai ketrampilan untuk mengungkapkan pikiran perasaan, dan sikapnya secara tertulis. Menulis ialah bentuk komunikasi tidak langsung (indirect) yang mengandalkan tulisan. Tarigan dalam Andayani (2009:28) mengatakan bahwa menulis atau mengarang ini sebagai tahapan menggambarkan 
suatu bahasa dalam bentuk tulisan sehingga pembaca dapat memahami pesan yang disampaikan penulis.

Hal ini sejalan dengan apa yang disampaikan oleh Alek dan Achmad (2010:106) yang mengemukakan menulis merupakan aktivitas untuk membuat suatu informasi dalam bentuk catatan atau asksara pada media tertentu. Kemudian Murtono (2010:27) turut mengatakan bahwa menulis ialah transfer ide, gagasan, pendapat, dan semacamnya yang tertuang dalam bentuk tulisan saja. Menulis berarti kemampuan untuk menggunakan pola kebahasaan dalam mempresentasikan suatu pesan atau gagasan (Rusyana dalam Syamsudin, 2012:3). Selanjutnya menulis juga dapat dikatakan melukiskan grafik yang membentuk suatu bahasa dan kemudain dimengerti oleh seseorang. Sehingga orang lain dapat memahami lambang grafik tersebut dan dapat dipastikan kalau mereka memahami gambaran grafik itu.

Sejalan dengan paparan para ahli diatas, dapat ditarik kesimpulan bahwasanya menulis ini ialah suatu aktivitas untuk menciptakan ide, gagasan,wawasan, pikiran, pendapat yang dituangkan dalam bentuk tulisan agar mampu dipahami oleh pembaca. Disamping itu, untuk menunjang kegiatan ini, penulis juga dituntut menguasai berbagai keterampilan berbahasa, penyajian, dan perwajahan.

\section{Tujuan Menulis}

Ada empat tujuan kategori penulisan bagi penulis pemula, yaitu: (1) penyampaian informasi dan pengajaran, (2) meyakinkan atau persuasif, (3) menghibur juga menyenangkan, serta, (4) mengutarakanatau menekspresikan hasrat emosi dengan membara (Tarigan, 2008:24).

Kemudian dalam kaitannya dengan tujuan penulisan, Harting (dalam Tarigan, 2008:25) menyimpulkan sebagai berikut: (1) Assignment purpose, tidak memiliki tujuan spesifik. Tulisan ditulis atas kemauan tersendiri individu, bukan karena ditugaskan; (2) Alturistic purpose, tulisan ini dibuat guna menghibur pembaca, menghilangkan kesedihan para pembaca, memahami pembaca serta bertujuan untuk membantu pembaca menjalani hidpnya menjadi lebih mudah lagi menyenangkan dengan naskah atau karyanya tersebut; (3) Persuasive purpose, tulisan ini berisi ajakan atau pemberi keyakinan kepada pembaca akan gagasan yang disampaikan; (4) Informational purpose, tulisan ini mermberikan penerangan kepada pembaca terkait dengan kebenaran informasi dan keterangan; (5) self-expressive purpose, tulisan ini sebagai media penulis untuk memperkenalkan dirinya atau karyanya kepada pembaca; (6) Creative purpose, seperti namanya, tulisan ini menjelaskan tentang nilai estetika dari sebuah tulisan; (7) Problemsolving purpose; bertujuan utuk memberikan kejelasan, secara detil tentang pemikiran atau gagasan penulis agar diterima baik oleh pembaca.

Berdasarkan pada tingkatnya, Iskandarwassid \& Sunendar (2011: 282) menyebutkan beberapa tujuan pembelajaran menulis, yaitu: (1) tingkat pemula, Menulis ulang, kesatuan bahasa yang sederhana, menulis pernyataan, dan menyusun paragraf sederhana, (2) penulis tingkat menengah, membuat pernyataan, pertanyaan, menyusun paragraf, menulis surat, mengarang cerpen, membuat laporan dan (3) tingkat lanjut, menyusun paragraf, menyusun paragraf, surat-menyurat, membuat karangan serta menulis laporan.

Berdasarkan paparan penjelasan diatas, dapat disimpulkan bahwa menulis itu memiliki tujuan : (1) tujua bagi peulis pemula: memberikan informasi, mengajar, menyampaikan, mendesak, menghibur, serta sebagai pengkspresian pendapat dan emosi yang kuat. (2) Berdasakan tingkatanya: (a) pemula : Menulis ulang, kesatuan bahasa yang sederhana, menulis pernyataan, dan menyusun paragraf sederhana, (b) penulis tingkat menengah, membuat pernyataan, pertanyaan, menyusun paragraf, menulis surat, mengarang cerpen, membuat laporan dan (c) tingkat lanjut, menyusun paragraf, menyusun paragraf, surat-menyurat, membuat karangan serta menulis laporan. (3) Tujuan menulis secara umum, yaitu: (a) assignment purpose, (b) altruistic purpose, (c) persuasive purpose, (d) informational purpose; (e) self-ekspressive purpose; (f) problem-solving purpose: dan $(\mathrm{g})$ creative purpose.

\section{Asas-Asas Menulis}

Suatu tulisan akan lebih dipahami oleh pembaca jika pengarang menerapkan asas-asas menulis. The Liang Gie (dalam Andayani, 2009:32) menyatakan terdaapat enam asas 
penulisan yang disebutnya dengan asas mengarang, ialah: (a) kejelasan (clarity), dapat diartikan sebagai tulisan yang jelas dan tidak meragukan, serta reliabel atau dapat dipahami dengan mudah dan mudah ditafsir (b) keringkasan (conciseness), hal ini berarti tulisan harus dibuat secara ringkas, padat dan jelas, tidak berlibihan, serta tidak terdapat pengulangan pada gagasan. (c) ketepatan (correctness), asas ini berisi aturan mengenai tulisan yang disampaikan kepada pembaca oleh pengarang dengan tepat dan cocok secara sempurna, (d) kesatupaduan (unity), asas kesatupaduan berarti tulisan yang ditampilkan dalam manuskrip harus sesuai dengan gagasan pokok dan tema penulisan karangan, (e) pertautan (coherence), asas ini menetapkan bahwasanya dalam suatu tulisan harus berkaitan satu kalimat antara dan yang lain, aliniea per alenia harus berkaitan (f) penegasan (emphasis), Yang berarti mewajibkan butir pokok ide yang vital diungkapkan dengan suatu penekanan tertentu sehingga karangan yang disajikan mempunyai kekuatan untuk para pembaca.

Pendapat Liang Gie senanda dengan Nurudin (2012:39) bahwa kegiatan menulis memerlukan beberapa asas-asas menulis diantaranya, yaitu (a) Jelas (clarity), (b) ringkas (consiseness), (c) tepat (correctness), (d) bersatu padu (unity), (e) pertautan (coherence), dan (f) tegas (emphasis)

Mengacu pada berbagai pendapat diatas, maka disimpulkan tulisan yang baik ialah tulisan yang dapat memaksimalkan keindahan dari segala unsur dan asas menulis, sehingga maksud dan tujuan yang dipaparkan penulis dapat didterima pembaca dengan baik, benar, dan jelas.

\section{Tahap-Tahap Menulis}

Andayani (2009: 29-30) menguraikan beberapa tahap-tahap dalam menulis antara lain, yaitu: (1) Langkah persiapan pra penulisan. Fase-fase ini meliputi: persiapan, pengumpulan informasi, perumusan masalah, definisi fokus, pemrosesan informasi, pembuatan skenario, interpretasi dan refleksi terhadap kenyataan, membaca, berdiskusim dan observasi, (2) Fase Inkubasi, tahaapan pemrosesan informasi yang dimiliki individu untuk membimbing mereka menemukan solusi dari permasalahan yang dicari. (3) fase inspirasi, yaitu tahapan dimana gagasan secara tiba-tiba datang kepikiran penulis, dan (4) Verifikasi, tahapan ini mengharuskan kita untuk memeriksa, menyeleksi, dan menyusun kembali tulisan sesuai dengan fokus tulisan.

Sedangkan menurut Alek dan Ahmand (2010 : 107) tahapan dalam penulis penjabarannya ialah sebagai berikut : (1) persiapan (preparation), terdiri dari: (a) kerangka rencana penulisan (outline), (b) mencari idiom yang mudah dipahami (eye catching), (c) mencari kata kunci (key word); (2) menulis (writing), meliputi: (a) kelogisan penulis, (b) membaca ulang setelah menyelesaikan suatu bagian, (c) percaya diri terhadap tulisan sendiri dan (3) editing, meliputi: (a) memperhatikan kesalahan penggunaan kata, tanda baca, dan tanda hubung, (b) memperhatikan kaitan antar paragraf, (c) membaca keseluruhan isi teks.

Berdasarkan beberapa pendapat di atas, dapat disimpulkan bahwa, menulis adalah kegiatan menghasilkan suatu gagasan atau informasi berupa catatan. Dalam hal ini terdapat langkah persiapan, langkah inkubasi, langkah inspirasi, langkah penulisan, dan langkah review/editing agar kalimat tetap teratur dan jelas.

5. Jenis-Jenis Tulisan

Kemampuan menulis dapat diklasifikasikan menjadi dua perspektif berbeda. Perspektif inilah yang disebut dengan aktivitas dalam output produk yang berjudul Performance of Write Ability. Pengelompokan ketrampilan ini disusun berdasarkan empat bentuk yaitu : (1) narasi, (2) eksposisi, (3) deskripsi, dan (4) argumentasi (Semi dalam Kusumaningsih, dkk., 2013:72-81).

Berikut ini akan dijelaskan secara singkat bentuk-bentuk tersebut: (1) Narasi adalah bentuk dialog atau teks yang bertujuan untuk menyampaikan rangkaian peristiwa atau pengalaman manusia berdasarkan pada perkembangan setiap periodesasi tertentu. (2) Eksplanasi adalah teks yang ditujukan sebagai penjelas suatu informasi. (3) Deskripsi merupakan perincian tentang objek sehingga dapat mempengaruhi emosi dan imajinasi pembaca atau pendengar, tertulis seperti melihat, mendengar, merasakan atau mengalami secara langsung objek tersebut. (4) Argumentasi berarti mengajak seseorang atau pembaca untuk melihat kebenaran pendapat atau perynataan penulis. Penjelasan bertujuan untuk menjelaskan sesuatu kepada orang 
lain, sedangkan diskusi bertujuan untuk membujuk orang lain. Membujuk orang lain secara objektif dan meyakinkan dengan bukti, alasan, dan penilaian.

Sejalan dengan pendapat di atas, Andayani (2009:35-36) mengemukakan bahwa metode yang dipilih untuk tujuan penulisan dapat menarahkan kita kepada berbagai bentukan penulisan, yaitu: narasi, ekposisi, deskripsi, serta argumentasi

(1) Narasi merupakan suatu bentuk wacana yang dimaksudkan untuk mengartikulasikan apa yang terjadi pada pembaca (Keraf dalam Anddayani 2009:35). (2) Eksposisi adalah narasi yang dimaksudkan untuk menjelaskan atau memberikan gagasan tentang sesuatu (Semi dalam Anddayani, 2009:35). (3) Deskripsi adalah kalimat yang memberikan informasi rinci tentang suatu tema, (4) Argumentasi adalah kalimat yang ditujukan kepada pembaca untuk membujuk dan mengajak melihat kebenaran suatu pendapat atau pernyataan seorang penulis (Semi dalam Anddayani, 2009:36).

Jadi, berdasarkan uraian di atas maka dapat disimpulkan bahwa terdapat banyak metode yang bisa dipilih seseorang untuk menjelaskan gagasan dalam tulisan, diantaranya yaitu: (1) narasi, (2) eksposisi, (3) deskripsi, dan (4) argumentasi.

\section{Model Pembelajaran Think Talk Write (TTW)}

Model Think Talk Write ini diklaim oleh Yamin dan Ansari (2008:84) menjadi salah satu model yang dapat diandalkan guna meningkatkan aktivitas dan komunikasi para siswa. Model pembelajaran yang diperkenalkan oleh Huinker dan Laughlin ini pada dasarnya dibangun atas kemampuan berpikir, berbicara, dan menulis. Proses pengembangan model pembelajaran ini diawali dengan keterlibatan murid dalam memikirkan masalah, serta berdialog mandiri setelah membaca, kemudian membagigagasan dengan kerabatnya sebelum menulis.

Model ini dapat dimaksimalkan jika implementasinya dijalankan secara perkelompok yang heterogen berjumlahkan 3 sampai 5 siswa. Mereka membaca bersama-sama, membuat catatan, mendengarkan, berbagi ide bersamasama kemudian menyusunnya melalui bentuk tulisan yang baku (Yamin dan Ansari, 2008:84). Hal ini juga dibenarkan oleh Hamdayani (2014:217) yang menyatakan hal yang serupa. Hanya saja dalam kelompok heterogen, beliau meminta murid tidak hanya membaca, tetapi juga melihat video pembelajaran yang nantinya akan disusun menjadi suatu tulisanl

Model pembelajaran TTW ini dapat melatih kemampuan siswa dalam menulis (Shoimin, 2014:212), karena pada model ini membuat komunikasi antar peserta didik menjadi lebih baik karena mereka saling bertukar pikiran. Aktivitas yang seerti inilah yang dapat memaksimalkan serta mebumbuhkan pemahaman konsep dan cara berkomunikasi melalui TTW (Huinker dalam Shoimin, 2014:212).

Model TTW berperan sebagai fasilitator untuk pelathan bahasa secara lisan sehingga penulisan menjadi lancar.

Hal ini sejalan dengan Ngalimun (2014:170) yang mengatakan bahwa model ini merupakan tipe model yang diawali dengan menggabungkan pikiran melalui konten bacaan, dan hasil bacaanya di sajikan dengan presentasi, diskuis, dan pada akhirnya akan menghasilkan laporan hasil presentasi.

Pengelompokan sintaks nya ialah: membaca, mencatat, menandai, presentasi, diskusi, dan pelaporan, Model TTW ini biasanya diawali dengan memikirkan bahan bacaan meliputi mendengarkan, meberikan kritikm dan memberikan pilihan solusi alternatif. Kemudian hasil bacaanya disampaikan dalam presentasi perkelompok yang berjumlah 3-5 orang secara heterogen, dan siswa dibebaskan uuntuk bertukar pendapat dengan temannya sebelum menulis.

Ada tiga tahapan penting dalam model pembelajaran ini yang wajib dikembangkan dalam pembelajaran berbasis argumentasi, yaitu:

1) Think

Think ini berarti berfikir, yang merupakan kegiatan yang dapat melatih cara berfikir siswa, dengan meliihat proses mereka membaca naskah yang diberikan kemudian dilihat dari catatan yang telah mereka baca. Siswa daapat membedakan, memetakan, serta menggabungkan gagasan yang tersaji dalam naskah dan menulis kembali dengan bahasa mereka sendiri.

Mencatat bearti mengalisis tujuan teks dan 
mencari keterangan terkait konten teks serta mempelajari bahan yang tertulis. Disamping itu menulis dapat memcu aktivitas berpikir saat proses membaca. Mencatat dapat meningkatkan wawasan siswa serta meningkatkan kemampuan berfiikir dan menulis mereka. Salah satu keunggulan dari metode ini ialah menciptakan catatan yang kemudian menjadi integral dalam lingkungan belajar (Wiederhold dalam Yamin \& Ansari, 2008:85).

Ketrampilan ini mencakupi kemampuan membaca dari baris kebaris dan hanya membaca gagasan pokoknya saja (Yamin dan Ansari, 2008:85), umumnya dianggap sebagai suatu cara berfikir. Kegiatan ini dilaksanakan siswa guna membantu mengidentifikasi permasalahan dan memecahkan permasalahan yan dikaji.

\section{2) Talk}

Talk merupakan kegiatan berkomunikasi antar siswa dengan menggunakan bahasa mereka sendiri. Pada fase ini siswa tetap di bagi dalam kelompok heterogen seperti langkah-langkah yang sebelumya, dan kemudian mereka bekerja sama dengan kelompoknya menggunakan Lembar Kerja Siswa (LKS). Didalam LKS terdapat soal-soal yang dikerjakan secara berkelompok. Tujuan dari kegiatan ini untuk menggabungkan gagasan dari masing-masing individu yang berbeda-beda. Siswa mengutarakan informasi dari tahap berbicara (think). Sehingga wawasan dapat terbangun melalui diskusi serta interaksi tiap kelompok.

Dengan berdisikusi diharapkan siswa menemukan solusi akan permasalahanpermasalahan mereka. Berkomunikasi dalam suatu diskusi ini dapat memfasilitasi serta mengkolaborasikan aktivitas yang meningkatkan pembelajaran dikelas. Al ini dapat terjadi saat siswa memiliki kesempatan untuk berbicara dan juga dapat menugnkapkannya secara tertulis.

Dengan berkomunikasi inilah dapat
memperlancar kemampuan murid dalam
mengutarakan ide-idenya. Pada dasarnya
komunikasi dua arah atau lebih ini dapat
meningkatakna pemahaman guru dan siswa-
siswi dikelas.

Kemudian, pentingnya fase ini adalah pemahaman para siswa terbangun melallui dialog interpersonal (secara individu), aktivitas sosial yang bermakna, dan siswa menggunakan bahasa sendiri untuk mengekspresikan ide, dengan teman sekelas serta membangun teori bersama, berbagi strategi, solusi, dan menciptakan definisi. Fase diskusi ini juga sebagai sarana pembentukan ide, meningkatkan penginternalisasian ide, serta mengevaluasi kualitas berfikir.

\section{3) Write}

Write berarti kegiatan dimana murid menuliskan hasil percakapan mereka pada lembar kerja yang telah disediakan. Menulis adalah proses penkonstruksian ide dengan teman, kemudian menuliskannya. Aktivasi ini memjembatani siswa dan guru dalam melihat perkembangan suatu konsep (Shoimin, 2014:213). Sejalan dengan pendapat tersebut, Shield (dalam Shoimin, 2014: 213) menyatakan bahwasanya menulis ini membatnu mewujudkan satu dari banyak tujuan pembelajaran, yaitu memberikan suatu wawasan terkait konten materi yang ia pelajari. Kreativitas menulis ini juga sebagai sarana pembantu tenaga pendidik untuk memonitor kesalahpahaman siswa terhadap gagasan yang sama antara mereka (Wisniowska dalam Yamin \& Ansari, 2008:88).

Pada fase menulis, kegiatan yang dilaksanakan siswa ialah menuliskan solusi dari permasalahan dan pertanyaan yang diberikan oleh guru, mengatur semua pekerjaan tanpa terkecuali agar enak dilihat dan diikuti, mengkoreksi semua tugas juga memastikan tidak ada tugas yang terlewatkan. Serta memastikan bahwasanya tugas terbaik itu adalah tugas yang lengkap, mudah dipahami, dan reliabel (dapat dipercaya keasliannya).

Jadi, paparan diatas menjelaskan pendapat dari para pakar yang menyimpulkan bawa model TTW ini merupakan model pembelajaran yang melatih keterampilan bahasa siswa dalam menulis yang diawali dengan kegiatan berpikir melalui bacaan/menyimak video, kemudian mencatat informasi yang didapat dari membaca/menyimak video, setelah itu dikomunikasikan kepada kelompoknya, dan tahap terakhir menuliskan hasil diskusinya secara individu.

\section{KESIMPULAN}

Kajian penelitian ini memberikan wawasan serta gambaran mengenai peningkatan motivasi murid dalam proses pembelajaran dan output 
menulis paragraf argumentasi. Keberhasilan peningkatan sikap ini juga ditentukan oleh berbagai macam pihak seperti peran guru, siswa, model pembelajaran dan media pembelajaran. Dengan guru yang tepat, peran aktif siswa, pennggunaan bahan pembelajaran yang maksimal dapat menghasilkan proses dan hasil yang baik pula. Manajemen kelas yang baik bagi guru mempengaruhi faktor positif motivasi siswa dan kinerja menulis mereka. Disamping itu, persiapan belajar yang matang juga mempengaruhi proses belajar yang baik, dampak dari proses yang baik inilah nantinya akan meningkatkan motivasi serta prestasi akademik mereka.

Pengimplementasian model TTW dalam menulis paragraf argumentasi yang dilakukan pada penelitian tindakan kelas (action research class) juga dapat meningkatkan motivasi dan kemampuan siswa.

Model ini menargetkan siswa sebagai subjek dari tujuan pembelajaran yang harus memaksimalkan potensi menulis dari dalam dirinya, baik secara berkelompok maupun perorangan, dan untuk guru mengimplementasikan model ini dapat meningkatkan motivasi serta kemampuan menulis sebagai implikasi dari hasi penelitian tindakan kelas melalui penggunaan media video berupa video berita. Penggunaan media video tersebut bertujuan untuk menraik minat siswa dalam menulis. Melalui video siswa menyimak isi yang ada didalamnya dan mencatat masalah atau informasi yang dapat ditemukan dari video berita tersebut, guru membentuk kelompok diskusi, guru memberikan tugas individu untuk membuat paragraf argumnetasi berdasarkan tema yang terdapat dalam video berita, kemudian guru melakukan refleksi yang bertujuan untuk menyusun tindak lanjut yang harus dilakukan.

Pertama, dengan menggunakan media video berita siswa menjadi lebih tertarik dan memperhatikan penjelasan guru, terlihat sebagian besar siwa tidak melakukan kegiatan yang tidak ada hubungannya dengan kegiatan pembelajaran. Media video berita tersebut merupakan permasalahan lingkungan yang umum terjadi dalam kehidupan nyata di kalangan masyarakat, misalnya meningkatnya kerusakan terumbu karang, dan peningkatan penggunaan kantong plastik di masyarakat. Namun, penggunaan media video berita juga mengalami kendala diantaranya, pada pelaksanaan tindakan siklus I penggunaan video berita yang berdurasi \pm 3 menit membuat siswa kesulitan dalam menggali informasi lebih lengkap karena durasinya yang terlalu cepat. Kemudian, pada siklus II peneliti menggunakan media video berita yang berdurasi \pm 7 menit dan tema yang menarik karena tidak asing bagi siswa, hal tersebut berhasil menarik perhatian, dan meningkatkan hasil menulis siswa.

Kedua, kegiatan berdiskusi pada fase menulis paragraf argumentasi mengarahkan siswa menjadi lebih kritis dan aktif untuk mengemukakan pendapat mereka mengenai pemecahan masalah yang disajikan oleh guru dengan menggunakan media video berita. Dengan berdiskusi siswa menjadi lebih cermat dalam isi gagasan yang dikemukakan dalam paragraf argumentasi lengkap, struktur kalimat efektif, fakta yang digunakan lengkap dan mendukung opini yang diberikan, diksi menarik, ejaan, dan tanda baca sudah jarang ditemukan kesalahan. Penerapan kegiatan diskusi/kelompok pada penelitian ini selain ada kelebihan juga mengalami kekuranganya, pada siklus I guru menerapkan pembagian kelompok yang ditentukan oleh siswa sendiri, hal tersebut berdampak pada kegiatan pembelajaran yang kurang kondusif karena terdapat siswa yang masih tidak mau membaur dengan kelompoknya, selain itu masih terdapat siswa yang tidak aktif dengan kelompok yang telah dibagikan. Hal tersebut membuat peneliti dan guru menentukan solusi untuk pemecahan masalahnya dengan pembagian kelompok secara heterogen dan diikuti dengan aktifnya guru memantau keseluruh kelompok sehingga proses diskusi menjadi terkontrol.

Ketiga, guru memberikan tugas individu untuk membuat paragraf argumentasi secara individu. Hal ini bertujuan untuk melatih dan mengeksplorasi kemampuan siswa.

Keempat, guru meningkatkan refleksi untuk mengetahui kemajuan maupun kekurangan siswa dalam proses pembelajaran menulis paragraf argumnetasisehingga guru dapat menemukan solusi atas kesulitan yang dihadapi oleh siswa pada saat menulis paragraf argumnetasi. 


\section{REFERENSI}

Alek, dkk. (2010). Bahasa Indonesia Untuk Perguruan Tinggi. Jakarta: Cipta Karya.

Angkasa. Sunendar, D. \& Iskandarwassid. (2008). Strategi Pembelajaran Bahasa. Bandung: Remaja Rosdakarya

Hanafi, H. F., \& Samsudin, K. (2012). Mobile Learning Environment System (MLES): The Case Of Android-Based Learning Application On Undergraduates Learning. arXiv preprint arXiv:1204.1839.

Hernawan, A. H., \& Resmini, N. Andayani.(2009). Pembelajaran

Terpadu di SD. Jakarta: Universitas Terbuka.

Huda, Miftahul. 2013. Model-model Pengajaran dan Pembelajaran. Yogyakarta: Pustaka Pelajar.

Kusumaningsih, W., \& Marta, R. P. (2016). Pengaruh pembelajaran berbasis masalah dan Discovery Learning terhadap kemampuan representasi matematis siswa SMP. JIPMat, 1(2).

Murtono, S. (2010). Seni Budaya Dan Keterampilan. Yudhistira Ghalia Indonesia.

Ngalimun. 2014. Strategi dan Model Pembelajaran. Yogyakarta: Aswaja.

Pratiwi, V. U., \& Setiyono, M. S. (2015). Aplikasi 'Guessing Games'untuk Meningkatkan Prestasi Siswa Dalam Speaking Bagi Siswa SD Kelas 2. In Prosiding Seminar Nasional \& Internasional.

Shoimin, A. (2014). Guru Berkarakter Untuk Implementasi Pendidikan Karakter. Yogyakarta: Gava Media.

Shoimin, A. (2014). 68 Model Pembelajaran Inovatif Dalam Berkurikulum 2013. Yogyakarta : AR-RUZZ Media.

Tarigan, H. G. (2008). Menulis: Sebagai Suatu Keterampilan Berbahasa. Bandung:

Yamin, M. dan Ansari, B.I. (2008). Taktik Mengembangkan Kemampuan. Individual Siswa. Jakarta: Gaung Persada Press 